\title{
The Caucasian Viceroy Michael Vorontsov and his Fraction
}

\author{
A. T. Urushadze, Z.N. Sulaberidze
}

For citation: Urushadze A. T., Sulaberidze Z.N. The Caucasian Viceroy Michael Vorontsov and his Fraction. Vestnik of Saint Petersburg University. History, 2020, vol. 65, iss. 2, pp. 375-391.

https://doi.org/10.21638/11701/spbu02.2020.203

The article deals with the patronage network of the first Caucasian Viceroy Michael Vorontsov. The research is based on the patronizing letters of the Viceroy to the Director of the Caucasian Committee Vladimir Butkov, as well as on the correspondence between Michael Vorontsov and employees and supporters. Michael Vorontsov's fraction consisted of representatives from various social groups: military, officials, local nobility, religious leaders, merchant circles. This diversity is explained both by the peculiarities of the personality of the Caucasian Viceroy, who combined the qualities of a nobleman, an army leader, a manager, and the socio-political conditions of the region which was led by Michael Vorontsov. The Caucasian Viceroy managed to form a reliable patronage network, which excluded the opposition and was the basis of the regional autocracy of the Viceroy. The administrative apparatus was made up of experienced officials who served with Vorontsov in the Novorossiysk region. Among the local population who supported the Viceroy was the Georgian princely clans, including the Orbeliani family, as well as the Armenian merchants. The formation of a loyal fraction was also necessary in the context of a confrontation with the Ministerial bureaucracy, whose ties with local institutions were suppressed or extremely formalized. Loyalty of clients was provided by promotions, awards and material prosperity. The system created by Vorontsov proved to be durable. His successors also relied in the capital on the Caucasian Committee and its Director, and within the Viceroyalty - on the same corporations and individuals who were patronized by the first Caucasian Viceroy.

Keywords: Russian Empire, Caucasus, Caucasian Viceroyalty.

Amiran T.Urushadze - PhD in History, Researcher, Southern Scientific Center of the Russian Academy of Sciences, 41, pr. Chekhova, Rostov-on-Don, 344006, Russian Federation; Associate Professor, Southern Federal University, 105/42, ul. Bolshaia Sadovaia, Rostov-on-Don, 344006, Russian Federation, aturushadze@sfedu.ru

Амиран Тариелович Урушадзе - канд. ист. наук, науч. сотр., Южный научный центр Российской академии наук, Российская Федерация, 344006, Ростов-на-Дону, пр. Чехова, 41; доц., Южный федеральный университет, Российская Федерация, 344006, Ростов-на-Дону, ул. Большая Садовая, 105/42; aturushadze@sfedu.ru

Zurab N. Sulaberidze - PhD in History, Associate Professor, Tbilisi Humanitarian Teaching University, 31, pr. monakha Gabriela Salosi, Tbilisi, 0144, Georgia; sulaberidze75@gmail.com

Зураб Николаевич Сулаберидзе - канд. ист. наук, доц., Тбилисский гуманитарный университет, Грузия, 0144, Тбилиси, пр. монаха Габриела Салоси, 31; sulaberidze75@gmail.com

The study was supported by the grant of the Russian Scientific Foundation (project No. 17-78-20117). Исследование выполнено за счет гранта Российского научного фонда (проект № 17-78-20117).

() Санкт-Петербургский государственный университет, 2020 


\section{Кавказский наместник Михаил Воронцов и его партия}

\section{А. Т. Урушадзе, 3. Н. Сулаберидзе}

Для цитирования: Urushadze A. T., Sulaberidze Z.N. The Caucasian Viceroy Michael Vorontsov and his Fraction // Вестник Санкт-Петербургского университета. История. 2020. Т.65. Вып. 2. C.375-391. https://doi.org/10.21638/11701/spbu02.2020.203

В статье рассматривается патронажная сеть первого кавказского наместника М. С. Воронцова. Основой исследования являются покровительственные письма наместника к управляющему делами Кавказского комитета В.П.Буткову, а также переписка М. С. Воронцова с сотрудниками и сторонниками. Партия М.С. Воронцова состояла из представителей различных корпораций: военных, чиновничества, местного дворянства, духовных лидеров, купечества. Такое разнообразие объясняется как особенностями личности кавказского наместника, сочетавшего в себе качества вельможи, армейского предводителя, хозяйственника, так и социально-политическими условиями края, которым руководил М.С.Воронцов. Если в Чечне, Дагестане и Черкесии пылала Кавказская война, то вся территория Закавказья, а также центральные районы Северного Кавказа ожидали административных, социальных и экономических преобразований, без которых имперская администрация рисковала и здесь вернуться к проблеме военного покорения. На основе изученного материала авторы статьи приходят к следующим выводам. Кавказскому наместнику удалось сформировать надежную патронажную сеть, которая исключала оппозицию и была основой регионального самовластия наместника. Среди верных сторонников наместника находились генералы, занимавшие ключевые посты в структуре Кавказского наместничества. Административный аппарат составляли опытные чиновники, служившие с М. С. Воронцовым в Новороссийском крае. Опорой наместника среди местного населения являлись грузинские княжеские фамилии, в том числе род Орбелиани, а также армянское купечество. Формирование верной фракции было необходимо и в контексте противостояния с министерской бюрократией, связи которой с местными институтами пресекались или предельно формализовались. Верность клиентов обеспечивалась повышениями, наградами и материальным достатком. Система, созданная М. С. Воронцовым, оказалась долговечной. Его преемники также опирались в столице на Кавказский комитет и его управляющего, а в пределах наместничества - на те же корпорации и отдельных лиц, которым покровительствовал первый кавказский наместник.

Ключевые слова: Российская империя, Кавказ, Кавказское наместничество.

In the summer of 1856, the Third Department of His Imperial Majesty's Own Chancellery received a letter from the southern border of the Empire with the critique of the course of actions of the first viceroy of the Caucasus M.S. Vorontsov (1844-1854). The reason behind writing of this letter was N. N.Murav'yev's dismissal from the position of viceroy; N.N.Murav'yev had been administering the Caucasus for less than 2 years (29 November $1854-22$ July 1856). The author, who disguised himself signing the letter as "a loyal son of his country", addressed the emperor, Alexander II, as follows: "You have sacrificed Murav'yev in favour of Vorontsov (my hand misgives me when I try to refer to him as 'prince') and his vile myrmidons"'. This purported that only such a man of principle and honesty as N. N. Murav'yev could wean off the legacy of M.S. Vorontsov

${ }^{1}$ Anonymous negative letter to Alexander II on dismissal of Murav'yev and on Vorontsov's and Bagryatinskiy's activities in the Caucasus // State Archive of the Russian Federation (SARF). Fund 109. Record 3. Doc. 74. Sheet 5. 
or, to quote the letter, to disengage from "the Vorontsov's track". In the eye of the "loyal son of his country", Vorontsov's viceroyalty proved to be the embodiment of "aristocratic despotism" based on unlimited authority and impunity of Vorontsov's party and his wife E. K. Vorontsova.

The anonymous exposé emphasized that Vorontsov and his fraction were above the law: "...something that the law forbade, prince Vorontsov saw as allowed" nal words of the anti-Vorontsov letter are peaceful and precautionary; the author gave a far from complimentary characteristic of the new viceroy, A. I. Baryatinskiy, and wrongly prophesied a collapse of the Russian politics in the Caucasus: "It is difficult to put dependence in a man (A. I. Baryatinskiy. - A. U., Z.S.) whose purpose and capabilities have not, as of yet, manifested themselves, and who is not on the whole prepared [for the role] and would have to, at least at the first time, to yield submission to the sordid people of the generation of the previous ruler Vorontsov..."3

The letter received no attention from the monarch and entailed no political consequences. Three years later, A. I. Baratyanskiy would take Shamil, a leader of the highlanders of Chechnya and Dagestan, captive, which proved to be a critical event in the history of the years-long Caucasian war. However, contrary to the misguided prophecy of the "loyal son of his country", a very important feature of the annexation of the Caucasus is recorded in his letter, namely that of the existence of an extended and powerful fraction of the first viceroy of the Caucasus M.S. Vorontsov. In one of the commentaries to the Vorontsovs' correspondence block, its publisher, P. I. Bartenev, compared Michael Semyenovich's power with the almightiness of the famous favorite of Ekaterina II, G. A. Potemkin. The power of the Russian high bureaucratic authorities, including viceroys and governors-general relied on monarch's trust and a network of patron-client liaisons. Expansion and stability of the latter eventually led to the development of parties or fractions which provided security and independence of the patron's position, in our case, the viceroy. If informal connections of M.S. Vorontsov in the capital's government institutions and, most of all, in the Caucasian committee have been somehow examined in the historiography ${ }^{4}$, patronage networks of the viceroy in the Caucasian region have not as yet been specifically researched. Among the works that explore corresponding topics, we would like to point out P. V. Ilyin's article on M.S. Vorontsov's coterie ${ }^{5}$, as well as a monograph by V. V.Lapin, which presents an analysis of the formation of a special corporate culture of soldiers and officers of the Separate Caucasian Corps ${ }^{6}$.

Personal letters from the Caucasian viceroy to the Head of the Caucasian committee V.P. Butkov, which have never been used for research of patronage networks in the south of the empire, are of high informational potential. The collection of letters includes only

2 Anonymous negative letter to Alexander II... Sheet 8.

3 Ibid.

${ }^{4}$ Lang D. The Last Years of the Georgian Monarchy, 1658-1832. New York, 1957; Rhinelander A. The Creation of The Caucasian Vicegerency // The Slavonic and East European Review. 1981. Vol.59, no. 1. P. 15-40; Rhinelander A. Prince Michael Vorontsov. Viceroy to the Tsar. Montreal, 1990; Bartlett R. Prince Michael Vorontsov: Viceroy to the Tsar by Anthony L. H. Rhinelander // The Journal of Modern History. 1994. Vol.66, no.3. P.660-661; Suny R. The Making of the Georgian Nation. Bloomington-Indianapolis, 1994.

${ }_{5}$ Il'yin P. V. M.S. Vorontsov and his coterie // Iz glubiny vremen. 1995. No. 4. P. 53-60; Lazarian S. S. Military-political and administrative-legal activity of Prince M. S. Vorontsov in the Caucasus region, 18451854. Pyatigorsk, 2012.

${ }^{6}$ Lapin V. V. Russian army in the Caucasian war $18^{\text {th }}-19^{\text {th }}$ centuries. St. Petersburg, 2008. 
twenty messages, where famous historic figures, particularly that of M. P. Shcherbinin, are mentioned alongside little-known names, whose biographies could only be retraced fragmentarily according to the prosopographic material. It is obvious that personal letters of the viceroy to V. P. Butkov reveal a large degree of patronizing consideration that M. S. Vorontsov demonstrated towards the persons he favoured and their interests.

In order to unveil figures that were in the viceroy's close circle, the article attempts to analyze already published recollections of his contemporaries, including officials who served their duty in the Caucasus during the viceroyalty of M.S. Vorontsov. Another source whose possibilities are explored in the present research is the partially published correspondence between M.S. Vorontsov and several officials, as well as letters of military officials deposited in the Vorontsovs' fund and the Russian State Archive for Ancient Acts.

The analysis of epistolary documents has already been conducted by researchers with the purpose of unveiling social and corporate foundations of the power of conspicuous statesmen. The Polish historian W. Tygielski was successful in reconstructing the "social system" of a magnate Jan Zamoiskiy who was the Grand Chancellor of the Crown and the Great Hetman of the Crown of Poland at the end of the $16^{\text {th }}$ century ${ }^{7}$. W. Tygielski's work is based on letter exchange between J.Zamoiskiy and his numerous supporters. Scrutiny of patronizing letters is no less reliable in reconstructing informal connections and patronage networks. In such letters, M.S. Vorontsov takes on an explicit role of the patron and protector of the members of his own party.

Letters from M.S. Vorontsov to V.P. Butkov date 1850 through 1856; most of them are written by Michael Semyonovich after the honorable dismissal from the position of the Caucasian viceroy ${ }^{8}$. The choice of the addressee of the patronizing letters is accounted for by both the informal relationship established between the viceroy and his administration with V.P. Butkov and the increasingly larger role of the latter in the Russian government.

V.P. Butkov was born on 10 April 1813 into the family of a famous linguist and historian specializing in the Caucasian studies, P. G. Butkov, who, apart from his research, also occupied the position of Head of Chancellery of chief governors in Georgia, K. F. Knorring (in 1801-1802) and P.D. Tsitsianov (in 1802-1803). V.P. Butkov started his official career in the Chancellery of the Military ministry, where he was employed in the position of correspondence clerk "without payment of salary until his abilities are revealed" 9

The abilities of the young official exceeded expectations of his superiors. The first witness to V.P.Butkov's tirelessness in the clerical work was the chancellery's director, M. M. Briskorn: “...Butkov is especially worthy of attention with regard to his abilities...", as he wrote to the military minister A. I. Chernyshev on 24 June 1833, asking permission of the latter to pay a one-time salary of 750 roubles to the industrious worker ${ }^{10}$. From that moment on, decorations in the form of orders (including foreign orders) and money grants became permanent companions to the office of the talented bureaucrat.

V.P. Butkov swiftly elevated through the official ranks: in 1834, he was collegiate secretary; in 1835, he - titular councillor; in 1837 - collegiate assessor; in 1840 - court

7 Tygelskiy V. A fraction that could not lose // Patron-client relationships in history and in contemporary time. Moscow, 2016. P. 116-148.

${ }^{8}$ Letter exchange between V.P. Butkov and M. S. Vorontsov on administering the Caucasian viceroyalty // Russian State Historical Archive (RSHA). Fund 1250. Record 2. Document 12.

${ }^{9}$ Case over service of a member of state council V. P. Butkov // RSHA. Fund 1250. Record 2. Document 1. Sheet 17.

${ }^{10}$ Ibid. Sheet 7. 
councillor; in 1842 - collegiate councillor; in 1844 - state councillor; in 1846 - active state counsellor. On 1 January 1850, V. P. Butkov was appointed Head of the Committee of Ministers while retaining his duty of administrating the Caucasian committee, and exactly a year later, the painstaking official was promoted to the rank of secretary of state ${ }^{11}$. In March 1850, emperor Nikolay I appointed V. P. Butkov the Chief administrator of the Secret committee for schismatics and abjurers of Orthodoxy ${ }^{12}$.

Therefore, by the middle of the $19^{\text {th }}$ century V. P. Butkov had become one of the most influential bureaucratic officials of the Russian empire, who was constantly in contact with ministers and their respective chancelleries and was noticed by the emperor. Michael Semeyonovich counted, rather justifiably, upon the long-standing bureaucratic dexterity of Vladimir Petrovich. V.P. Butkov was connected with the Caucasian administration by informal and trusted ties. In the adversarial relationship between the Caucasian viceroy and the ministers insofar as various questions of administrative arrangements and civil development of the southernmost region of the empire were concerned, the chief administrator of the Caucasian committee invariably took M.S. Vorontsov's side. Letters from V. P. Butkov to Head of Chancellery of the Caucasian viceroy S. V. Safonov contain some rather forthright rhetoric. For instance, in a letter of 28 June 1846, the metropolitan bureaucrat noted the following in his description of the difficulties of his confrontation with ministers: "I am convinced that despite all the authority given to viceroy, the region won't be settled up until it is granted, albeit even for a limited time, independent administration, such as that that Poland and Finland have; that is, basically, until such time when ministers have no say in the Caucasian matters. I know that it is impossible, but I believe it is necessary"13.

Already after he had left the Caucasus, M. S. Vorontsov was all but made to give a detailed report on his spending of extraordinary sums, which he was personally in charge of. In January 1855, the former viceroy asked for V. P. Butkov's help and assistance in organizing an informal reviewing of all expenses made ${ }^{14}$. M. S. Vorontsov emphasized that he addressed V. P. Butkov "in full trust as since the beginning of my service in the Caucasus, I have constantly experienced and seen evidence of your incessant wish to rightly help the high Caucasian administration in the difficult and complicated service"15.

Another question is of equal importance: what motivated V.P. Butkov, who grew higher in rank and more influential year by year, to lobby the interests of the Caucasian viceroy and his fraction? First of all, the chief administrator of the Caucasian committee was a protégé of military minister A. I. Chernyshev, who was informally in coalition with M.S. Vorontsov. Unlike other ministers, who were jealous of the rights and privileges that constituted integral part of the Caucasian viceroyalty, the head of the Military ministry

${ }^{11}$ Records on service by officials of the Committee of Ministers chancellery for $1851 / /$ RSHA. Fund 1349. Record 5. Document 15. Sheet 10-18.

12 On appointment of chief administrator of the Caucasian committee, an activel state councillor Butkov, assistant chief administrator of the Ministers Committee, with his current position being maintained by him. See same sheet on his being appointed chief administrator of the Ministers committee and Secret committee for schismatics and of abjurors of faith, as well as his being dismissed from $1^{\text {st }}$ division of His Imperial Majesty's Own Chancellery // RSHA. Fund 1268. Record 3. Document 188. Sheet 21.

${ }^{13}$ Letter exchange between V.P. Butkov and chief administrator of the viceroy's chancellery S. V.Safonov on administering the Caucasian viceroyalty // RSHA. Fund 1250. Record 2. Document 10. Sheet 152.

${ }^{14}$ Letter exchange between V.P. Butkov and M.S. Vorontsov on administering the Caucasian viceroyalty // Russian State Historical Archive (RSHA). Fund 1250. Record 2. Document 12. Sheet 35.

15 Ibid. 
was absolutely content with the viceroy's full accountability for successes, and what's more important, defeats in the unpredictable Caucasian war. Half-tzarist authority of the Caucasian viceroy presented no threat to A. I. Chernyshev's standing and did not constrain his hierarchical position, as another bureaucratic role was that of the Chairman of the Caucasian committee. In this regard, V.P. Butkov held exactly to the course of his immediate superiors. Secondly, a career of another influential bureaucrat, state secretary M. P. Pozen, collapsed before the eyes of Butkov; Pozen became a victim of M.S. Vorontsov's fight for maximum independency from tutelage of ministers and chief governors ${ }^{16}$.

M. P. Pozen's defeat in the hierarchical duel with M.S. Vorontsov became inevitable given the complete confidence that Nikolay I put in the latter; the confidence proved to be the most important and probably critical resource of the Caucasian viceroy in his race for power. V.P. Butkov, who took the position of the dismissed M.P. Pozen, was well aware of this. "Hold on firmly to Prince Michael Semeyonovich. He is now almighty with the trust the monarch puts in him", V.P. Butkov advised in the summer of 1845 an official of the Ministry of finance and a scientist Y.A. Gagemeister, who was in service at the Caucasus during the time ${ }^{17}$. Pro-Vorontsov eagerness of the chief administrator of the Caucasian committee is explained by this.

M. S. Vorontsov's party included people of many groups: military, officialdom, local nobility, spiritual leaders, merchants. Such diversity can be attributed both to character traits of the Caucasian viceroy, whose personality embraced features of a nobleman, army leader, economist, and the social and political landscape of the region that was in Vorontsov's charge. While the Caucasian war was at white heat in Chechnya, Dagestan and Cirkassia, the whole Transcaucasian region, as well as the central parts of the Northern Caucasus, awaited administrative, social and economic conversions without which the imperial administration would have risked returning to the problem of "conquest of hostile land"18 here, too.

\section{Generals}

Three generals played an important role in Vorontsov's party: V. O. Bebutov, M.Z. Argutinskiy-Dolgorukiy and N.S.Zavadovskiy. Vasiliy Osipovich Bebutov occupied the second-important (after the viceroy) position in the Russian administration in the Caucasus - the head of the civil administration of the Transcaucasian region. He took the office from general P. A.Ladinskiy, who was dismissed on 8 November $1847^{19}$. The dismissal of the latter was a direct consequence of his open opposition towards the viceroy and his immediate circles. Petr Antonovich Ladinskiy believed that he was unlawfully excluded from the decision-making in matters pertaining to administrating the region and spoke openly about $\mathrm{it}^{20}$. In reality, however, P. A. Ladinskiy enjoyed full trust of Vorontsov at

16 See more: Korf M. A. Memoirs. Moscow, 2003. P.337-338; Shcherbinin M. P. Memoirs of Mikhail Pavlovich Shcherbinin. Moscow, 1876. P. 19-20.

17 Letter exchange between V.P. Butkov and chief administrator of the viceroy's chancellery S. V.Safonov on administering the Caucasian viceroyalty // RSHA. Fund 1250. Record 2. Document 10. Sheet 45.

18 Mil'utin D. A. Thoughts on different courses of action in the Caucasus // Handwritten manuscript department of the Russian State Library. Fund 169. Book 19. Item 5. Sheet 7.

19 Acts collected by the Caucasian Archaeographic Commission (AAC). Tiflis: Typography of the chief administrator for civil matters in the Caucasus, 1885. P. VI-VII.

20 As recollected by A. A. Kharitonov // Russkaya starina. 1894. Book 6. P.71-72. 
first, and the latter assigned the former with tasks requiring decisions in matters of no small importance. It was Ladinskiy who engaged in settling differences between Agalar landlords and peasant populace of the Muslim provinces of the Southern Caucasus. It was also he who was in charge of investigation of notable case of a lost mail suitcase that contained 40 thousand roubles in silver ${ }^{21}$. Ladinskiy failed in both undertakings. The Agalar, as it became obvious several years later, did not become a reliable pillar of the empire in the region. Prince Yasse Andronikov and official Forostovskiy, who were suspected of the theft of the government money, were never proven guilty.

A. P. Yermolov expressed doubts regarding Ladinskiy's potential in his letters to the viceroy: "I do not know where he (P. A.Ladinskiy. - A. U., Z.S.) acquired his working knowledge of civil matters, but previously he did not demonstrate such abilities" 22 , the former "proconsul of the Caucasus" wrote as early as February 1846. A year later, A. P. Yermolov took a favourable view of the change in the Vorontsov's administration: "I do not suppose that we could regret the dismissal of Ladinskiy, who excelled in affairs but only in those of roguish nature. I know this persona well who could be capable of being a spy! Bebutov, on the other hand, is a man of business who can be trusted"23.

V. O. Bebutov's appointment was a risky move on the part of the Caucasian viceroy. The matter is that Vasilliy Osipovich was involved in the case of counterfeit documents issued by the Akhaltsikhe administration to the Turks that were being relocated from the territory that was ceded to the Russian empire according to the Treaty of Adrianople of 1829. M.S. Vorontsov petitioned the Caucasian committee for dismissal of the case, but it was only dismissed after benign interference of the emperor Nikolay I, which redeemed V. O. Bebutov from continued investigation and possible court hearing ${ }^{24}$.

M.S. Vorontsov was right. The new head of the civil administration became the key figure not only in the region's administration, but in the viceroy's party as well. We would like to note that Bebutov began to take part in the decision-making concerning significant administrative projects before his official appointment. Already in October 1847, the viceroy sent "Agalar issue" papers to V. O. Bebutov to be revoked 25 .

Vasiliy Osipovich emphasized his unquestionable loyalty to the viceroy even in personal letter exchange with A.P. Yermolov, who thought highly of him; Yermolov unsuccessfully tried to provoke the head of the civil administration into a dangerous openness by asking questions on the reasons why his cousin, Sergey Nikolayevich Yermolov, had been dismissed from the position of the Tiflis Military Governor ${ }^{26}$.

During his viceroyalty in the Caucasus, M.S. Vorontsov aspired to realize his project of "a new service man" for employment in the southern region of the Russian empire. Opening of new educational institutions and regularly sending Caucasian-born students to universities in Russia were both aimed at creation of universally versatile bureaucrats. V. O. Bebutov and M.Z. Argutinskiy-Dolgorukiy were alumni of the Tiflis school for noble

${ }^{21}$ In relation to the viceroy of the Caucasus on the study of the loss of a mail suitcase with 40 thousand rubles in silver that happened in 1844 // RSHA. Fund 1268. Record 2. Document 207. Sheet 3.

22 Caucasian letter, A. P. Yermolov, M. S. Vorontsov. St. Petersburg, 2011. P. 116.

23 Ibid. P. 188.

24 As recollected by A. A. Kharitonov... P. 73.

25 Letters by generals // Russian State Archive for Ancient Acts (RSHAA). Fund 1261. Record 4. Document 165. Sheet 46.

${ }^{26}$ Alexey Petrovich Yermolov. His letters to prince V.O. Bebutov // Russkaya starina. 1872. Vol. V, book 5. P. 442. 
youth and set the example for successfulness of the empire's social engineering. It is no coincidence that the names of the two generals were mentioned by the viceroy in his speech at the grand opening of the Caucasian educational district on 5 April $1849^{27}$.

V.O.Bebutov participated in all novelties that came along with the viceroy's activities. In 1850, the Caucasian society for agriculture was founded in Tiflis. M. S. Vorontsov was elected president, and V. O. Bebutov - vice-president ${ }^{28}$. The Caucasian division became the first division of the Imperial Russian geographical society in 1851, with its office in Tiflis. The Caucasian viceroy was patron of the division, and V.O. Bebutov became his assistant and head of the division ${ }^{29}$. Vasily Osipovich was with the governor not only formal terms, but, probably, on friendly terms. According to the memoirs of A.M. Dondukov-Korsakov, who served as adjutant to M.S. Vorontsov in 1846-1852, V. O. Bebutov usually kept company with the viceroy over an evening card game ${ }^{30}$.

M. Z. Argutinskiy-Dolgorukiy proved to be both a talented combat general and an efficient administrator during the viceroyalty of M.S. Vorontsov. The immense military experience gained by Moisey Zakharovich in the fights with highlanders in the North-Eastern Caucasus predetermined, in large part, his acquiring a position in Vorontsov's immediate circle. Famously, the viceroy especially valued practical military and administrative expertise in his subordinates. After several expeditions undertaken by M.Z. Argutinskiy-Dolgorukiy in 1845-1846 in Dagestan, he was appointed military governor of Derbent on 1 January 1847, and several months later he occupied the position of Army commander of the Caspian region, which embraced the territory of the Derbent governorate and Samur and Darginskiy districts ${ }^{31}$. In the same year, M.Z. Argutinskiy-Dolgorukiy played a key role in the battle of Salty which resulted in the victory of the Russian Caucasian Forces. Upon a petition of the viceroy, the general was decorated with the prestigious order of the White Eagle ${ }^{32}$. The next year M.Z. Argutinskiy-Dolgorukiy was made chevalier of one of the highest Russian orders, that of Saint Alexander Nevsky for lifting the siege from the mountain village Akhty. M.S. Vorontsov in private conversations with Nikolay I distinguished successful actions of M.Z. Argutinskiy-Dolgorukiy. He wrote about that to Moisey Zakharovich in the summer of 1849: "You can picture how flattering it was to talk about you and your affairs, and the monarch eagerly awaits news about your progress"33.

M.Z. Argutinskiy-Dolgorukiy defined the tactics of military actions of the Russian Caucasian Forces at the most difficult theatre of the Caucasian war, in Dagestan and Chechnya. A relationship of trust developed between him and the viceroy as evidenced by flourishing unofficial letter exchange from 1849 to 1853. It was M.Z. Argutinskiy-Dolgorukiy in whose charge the Caucasian viceroy placed his son, S. M. Vorontsov, whose service was one of the recurring themes of the correspondence between Michael Semenovich

27 Caucasus. 1849. No 18 (dated 30 April). P. 70.

28 Caucasus. 1850. No. 30 (dated 15 April). P. 118.

29 Caucasus. 1853. No. 14 (dated 21 February). P. 57.

${ }^{30}$ Dondukov-Korsakov A. M. Prince Mikhail Semenovich Vorontsov // Starina i novizna. 1902. Issue 5. P. 123.

31 Caucasusian calendar for 1856. Tiflis, 1855. P. 574.

32 Ibid.

33 Private letter exchange between aide-de-camp general, prince Argutinskiy-Dolgorukov, and generalin-chief of the Russian Caucasian Forces and accidentally with several other individuals // Handwritten manuscripts department of the State Russian Library (HMD of the RSL). Fund 32. Record 1. Document 1. Sheet 24 . 
and Moisey Zakharovich. For instance, in August 1849 M.Z. Argutinskiy-Dolgorukiy conveyed the following to the viceroy: "Prince Semyon Mikhailovich serves assiduously and fulfills his responsibilities with great precision. This I report to Your Highness not in your capacity of parent of Semyon Mikhailovich, but in your capacity as our general in chief, because captain Prince Vorontsov richly deserves my attestation as a young man with dashing spirit and as a disciplined performer of service. He only regrets not having been distinguished yet in such a way that would give him the right to be noticed by his superiors, which he deserves" 34 .

M.S. Vorontsov valued attention that M.Z. Argunitskiy-Dolgorukov gave to his son but sometimes the general in chief had to curb the enthusiasm of his loyal subordinate. In September 1849, M.S. Vorontsov wrote, "Now it remains for me to thank you (M.Z.Argunitskiy-Dolgorukov. - A. U., Z.S.) yet another time for all your beneficence to Semyon Mikhailovich. I am afraid that colonelcy is too early for him, but in this case let him be given Order of St. Anne of second degree" 35 .

The viceroy entrusted M.Z. Argunitskiy-Dolgorukov with carrying out secret negotiations with the famous naib Shamil Hadji Murad who got into the Russian position on 23 November 1851. M.S. Vorontsov was not content with such an outcome as he counted on employing Hadji Murad against imam Shamil; in his letter to M.Z. Argutinskiy-Dolgorukiy of as early as 24 November 1851, the viceroy emphasized that "Even though Hadji Murad is weak, he is of much more use to us showing his teeth to Shamil in the land of Avars, rather than leaving the land and appearing before us" ${ }^{36}$. Hadji Murad, being an honorary captive, ceased to be useful to M.S. Vorontsov, which in no small part predetermined the impending death of the former naib Shamil.

Several telling details of their correspondence speak in favour of close, informal relationships that bound together the viceroy and M.Z. Argutinskiy-Dolgorukiy. As early as late 1840s the health of the general-in-chief of the Caspian region army began failing him as the result of many military expeditions which were pursued in austere environments. Moisey Zakharovich was consulted by the viceroy's personal doctor, E. S. Andreevskiy ${ }^{37}$, who in his turn produced a significant impact on the work of Vorontsov's administration. The viceroy finished off his letters to M. Z. Argutinskiy-Dolgorukiy with an exclusive version of his signature: "your comrade Prince Vorontsov".

Nikolay Stepanovich Zavadovskiy had occupied most important position of general-in-chief on the Caucasian front and at the Black sea since 1848. In the memoirs of general M. Y. Ol'shevskiy, the picture of N. S. Zavadovskiy is painted in unsavory light, but his official elevation is directly attributed to the patronage of the viceroy: "He (N.S.Zavadovskiy. - A.U., Z.S.) was so good at dance attendance and playing harmless simpleton that count Vorontsov, enchanted by his modesty and infinite docility, saw in him most honest, most loyal servant to the tzar... With honours and benevolence of his powerful patron thick upon him, we cannot say that he left fond memories of himself" 38 . N. S. Zavadovskiy was quick to evaluate the bureaucratic weight of the first Caucasian viceroy and strained

34 Private letter exchange between aide-de-camp general... // HMD of the RSL. Fund 32. Record 1. Document 1 . Sheet 24 .

35 Ibid.

36 Private letter exchange between aide-de-camp general... // HMD of the RSL. Fund 32. Record 1. Document 3. Sheet 134 .

37 Ibid.

38 Ol'shevskiy M. The Caucasus 1841 through 1866. St. Petersburg, 2003. P. 141. 
after being admitted to his close circle. This is evidenced by the exalted intonation of his letters to M.S. Vorontsov, which to some extent supports M.Y. Olshevskiy' account. In December 1845, in his letter wishing the viceroy a happy New year, Nikolay Stepanovich wrote, "Quite content with your highness's benevolence, there is only one thing I pray to the supreme creator about - that your precious life be kept under his holy cover for many years to come, for glory of all of Russia, for good of the Caucasian region!" 39 . M. S. Vorontsov was very attentive to the content and intonation of letters from his immediate colleagues. P. A. Ladinskiy's contemporaries attributed his fall to a paragraph in his letter where, describing his feelings regarding taking over of the mountain village of Salty, the head of the civil administration quoted the inscription on the medal "In remembrance of the Patriotic was of 1812": "Not to us, not to us, but in Thy name". The viceroy understood that phrase as hinting that the victory was achieved not through his talented generalship, but only through higher powers - and there P. A. Ladinskiy's destiny was decided ${ }^{40}$. Letters from N.S. Zavadovskiy are direct and flattering, but naturally, it would be an unforgivable simplification to attribute M.S. Vorontsov's patronage only to the intonation of letters. It is probable that the viceroy hoped that peaceful resolution of the conflict with the Circassians was possible. To this end, barter trade and negotiations with Circassian nobles were held in the Kuban region. N. S. Zavadovskiy made efforts in this vein, and the viceroy counted on his experience and his liaisons with the locals.

The Caucasus, as well as other borderlands of the Russian Empire, was administrated by the military, that is why the relationships of trust with the elite of generals was a defining factor of stability and efficiency of a viceroy's power. V.O. Bebutov, M.Z. Argutinskiy-Dolgorukov and N.S.Zavadovskiy all held key positions in the regional administration system, and all of them were tied to M.S. Vorontsov by patron-client relationships. The dismissal of P. A. Ladinskiy timely beheaded the Fronde that could have formed around him.

\section{Officials}

Matters of civil administration of the Caucasian region during M.S. Vorontsov's administration were decided predominantly in the viceroy's chancellery, which was headed by Stepan Vasil'yevich Safonov, whose loyalty and service were tried and tested multiple times. He started his career in 1825 in the chancellery of M. S. Vorontsov, who at that time held the position of governor general of Novorossiya and Bessarabia. S. V. Safonov, like another influential official of the Caucasian administration, Mikhail Pavlovich Shcherbinin, was M.S. Vorontsov's project; Prince valued their abilities before his appointment the Caucasian viceroy, and subsequently he brought them over to Tiflis with him. It should be noted that the "intervention" of the Novorossiya officials into the Caucasus when M.S. Vorontsov took office was not wide-scale. The record from "Record on staff changes of Chief administration of the Transcaucasian region" of 1846 to 1847 demonstrates that transfers of officials from Novorossiya to the Caucasus were relatively rare. In 1846, three such cases of appointments to positions higher in rank were registered: office accountant of the Accounts department of the viceroy's chancellery (the viceroy appointed titular

${ }^{39}$ Letters by generals // RSAAA. Fund 1261. Record 4. Document 165. Sheet 59-59 on the reverse.

40 As recollected by A. A. Kharitonov... P. 71. 
councillor Fedorovskiy, who formerly served in Odessa branch of commercial bank, to that position), regional architect for Caspian region (city architect of Odessa, Cambiadgio, was given this position) and district associate judge of Ukhanashkharskiy district of the Signagi uyezd (retired praporshchik Pavlovskiy, who formerly served as assistant to head of the Jewish colonies of the Kherson governorate $)^{41}$. Among the young officials of the viceroy's chancellery, only one out of twelve was had formerly served in the chancellery of the governor general of Novorossiysk and Bessarabia, and another one out of twelve was alumnus of Richelieu lyceum in Odessa ${ }^{42}$.

However, it was "Novorussian" old-timers who played the key role. S. V. Safonov was in correspondence with V.P. Butkov regarding a wide variety of questions pertaining to administrating the Caucasian region: ranging from the question of devising special uniforms for officials of the Caucasian administration to determining the strategy for standing in opposition to ministers and chief governors. The relationships of the chief administrator of the Caucasian committee and head of the chancellery of the Caucasian viceroy were trusting but official. V.P. Butkov took a critical view of many aspects of the work of the Vorontsov's administration, but that he conveyed not to S. V. Safonov but to Y. A. Gagemeister, noting that sending proposals on improvement of the viceroy's chancellery directly to its head was "quite inconvenient" 43 . Nevertheless, this did not interfere with the cooperative work of these two talented bureaucrat officials.

During the period of S. F. Safonov's service in M. S. Vorontsov's administration, he acquired full trust of the latter. The viceroy entrusted the head of his chancellery with most responsible missions, including representation of the interests of the Caucasian region to the emperor in person. In the "Prince Vorontsov's archive", a transcript of conversation between S. F. Safonov and Nikolay I dated 28 September 1846 is given. The head of the viceroy's chancellery freely and in well-argued manner represented M.S. Vorontsov's point of view regarding many an administrative and financial question ${ }^{44}$. And even though Safonov did not succeed in persuading the tsar to allow free trade in the Caucasus, the content of this highly informative conversation demonstrate the high status of the emperor's collocutor in the political system of the viceroyalty.

S. V. Safonov was generously rewarded with the viceroy's patronage. On 19 December 1851 he was promoted to the rank of privy councillor along with acquiring a position in the Senate. In the new position, S. V. Safonov did not neglect either duty and became famous for his revision of the Penza governorate in 1858 and 1859.

M.P.Shcherbinin, who, just like S. V.Safonov, began his service with M.S. Vorontsov in 1825 , became a senator, too. M.P. Shcherbinin took part in the viceroy's expedition to Dargin in 1845, and the next year, already in the rank of active state councillor, he was appointed the head of the expedition's chancellery and the head of the secret sub-department of the Vorontsov's chancellery ${ }^{45}$. After S. V. Safonov's transfer to the Senate, M. P. Shcherbinin was entrusted with heading the viceroy's chancellery. Some of the officialdom enthusiastically welcomed this change in the Caucasian administration. As remembered by a

${ }^{41}$ On changes in staff of the Chief administration of the Transcaucasian region // RSHA. Fund 1268. Record 2. Document 211. Sheets 6, 59, 63.

42 Ibid. Sheet 70.

${ }^{43}$ Letter exchange between V.P. Butkov and chief administrator of the viceroy's chancellery S. V. Safonov on administering the Caucasian viceroyalty // RSHA. Fund 1250. Record 2. Document 10. Sheet 82.

44 Prince Vorontsov's archive. Book XXXVIII. Moscow, 1892. P. 383-408.

45 AAC. Tiflis, 1885. P.XXXIV. 
Caucasian old-timer official V. A. Dzybenko, "When he (M. P. Shcherbinin. - A. U., Z. S.) took the office, administrative matters gathered pace and became more wholesome, without strained meaning, mendacity, and unwanted contrivances" 46 .

At the beginning of 1855, when M.S. Vorontsov had already left the Caucasus, M.P.Shcherbinin was still in the government service in the region, but his career could have finished under the new viceroy N.N. Murav'yev who wrote an "open" letter to A.P. Yermolov in February 1855 criticizing the state of affairs in the southern border regions $^{47}$. It was expected that the new viceroy would carry out a total revision of the Vorontsov's heritage; revision of the officialdom was expected as well.

Michael Semeyonovich never forgot about M.P.Shcherbinin or abandoned him. In his letter to V.P.Butkov of 19 January 1855 the former Caucasian viceroy called M.P. Shcherbinin "comrade-in-arms of 30 years' standing and a true friend" 48 . In his letter, S.M. Vorontsov conveys that he advised M.P. Shcherbinin to "become friends" with N. N. Murav'yev, but that he doubts the possibility and, in fact, asks for assistance in transferring his loyal official and friend to the Senate, "as it had been done for S. V. Safonov". M.S. Vorontsov admits that he himself no longer has the opportunity to recommend the official for the position and counts on V.P. Butkov's help. In addition to the above, Michael Semeyonovich emphasized the importance of the matter in the following words: “...I make this humblest request to you to ask your opinion on how to assist Shcherbinin whom I love wholeheartedly and with whom I have been in service for 30 years and share a most trusted relationship" ${ }^{49}$. On 24 January 1856, M. P. Shcherbinin was promoted to the rank of privy councillor and appointed to the Senate. Thereby, he followed exactly the career path that S. V. Safonov had taken five years earlier.

Out of the officials who were doing their service in the Novorossiya and consequently turned out to be in the administration of the first Caucasian viceroy, A. M. Fadeyev, father of a famous publicist R. A. Fadeyev and grandfather of an outstanding reformer S. Y. Vitte, should be mentioned. Andrey Mikhailovich had come a long way of a bureaucrat official and had a chance to serve in various institutes of the administration. From 1815 through 1818, A. M. Fadeyev occupied the position of the assistant to chief judge of Guardianship office of Novorossiya; in 1818 to 1834, he was already the chairman of the Ekaterinoslav colony of foreign re-settlers. While being in the office, A. M. Fadeyev became close friends with M.S. Vorontsov. In the summer of 1825 , the official was accompanying the governor general of Novorossiya in his travel across settlements of foreign colonists of the vast region. In the autumn of the same year, M. S. Vorontsov entrusted A. M. Fadeyev to officially greet emperor Alexander I in the Molochan colonies of the Taurida governorate ${ }^{50}$.

In 1835, the official was transferred to the Astrakhan governorate to take the position of the chief guardian of the Kalmyk, and four years later, he assumed a new position again: this time he set off for Saratov governorate where from 1841 to 1846 he performed duties of the civil governor. His bond with M. S. Vorontsov did not discontinue, quite the opposite, in fact. The thing is that peasant farms owned by the governor of the Novorossiya

46 V. A. Dzybenko memoirs // Russkaya starina. 1879. Vol. XXIV, issue 4. P. 670.

47 A letter from N.N. Murav'yev to A.P. Yermolov // Russkaya starina. 1872. Vol. VI, issues 7-12. P. 542-543.

${ }^{48}$ Letter exchange between V.P. Butkov and M.S. Vorontsov on administering the Caucasian viceroyalty // Russian State Historical Archive (RSHA). Fund 1250. Record 2. Document 12. Sheet 23.

49 Ibid. Sheet 30.

${ }^{50}$ Fadeyev A. M. Memoirs 1790-1867. Moscow, 2017. P. 103-105. 
were in the Saratov governorate. M. S. Vorontsov asked A. M. Fadeyev to facilitate delivery of information on the state of affairs in these farms and their management. Judging by the content of letters from Michael Semyonovich to the governor of Saratov in 1842 and 1843, Andrey Mikhailovich gave willing services concerning these requests from his former superior $^{51}$. It is telling that these liaisons with M. S. Vorontsov are overlooked in A. M. Fadeyev's memoirs.

In 1846 A.M. Fadeyev asked for resignation as a result of numerous revisions and official investigations with which L. A. Perovskiy, minister of internal affairs, tormented the Saratov governor. A.M. Fadeyev described his dire situation to S. V.Safonov, whom he had known since his service in Novorossiya. The Head of Vorontsov's chancellery reported A. M. Fadeyev's situation to Michael Semeyonovich, and the Caucasian viceroy found a position for his old employee who used to help with administrative responsibilities in the Council of head department of the Transcaucasian region. It is noteworthy that L.A.Perovskiy and his official coterie, as can be inferred from the letter exchange between V.P. Butkov and S. V.Safonov, were interfering with the official's nomination for the position in the Caucasus ${ }^{52}$. From that moment on, A. M. Fadeyev's career continued in the Caucasus: in 1848 he was promoted to the rank of active state councillor; in 1850, he received an appointment as the head of expedition for state property under Head department of the Transcaucasian, and in 1858 he accepted the title of privy councillor ${ }^{53}$.

Various administrative reforms and modernization of civil life in the Caucasian region called for experienced bureaucrats able to endure significant official stress. Personal trust of the viceroy was no less important. Under the conditions of official and hierarchical opposition with ministers and chief governors ${ }^{54}$, M.S. Vorontsov preferred to appoint well-tried and well-familiar officials to occupy key administrative positions. The first Caucasian viceroy was generous when it came to rewards and promotions; it stimulated both hard work and loyalty to his party. As V. P. Butkov wrote to Y. A. Gagemeister, "I believe that having 4 thousand roubles in silver, you it is always possible to have good employees in the Council, especially for Prince Michael Semeyonovich, who is eager both to reward and promote" 55 .

\section{Georgian nobles and Armenian merchants}

One of the first notable reforms that M.S. Vorontsov undertook was the case of official recognition of Georgian princely and noble families. As the viceroy wrote to military minister A.I. Chernyshev on 30 September 1845, "Even as I was passing through the region of Imereti, and as soon as I reached Tiflis, I received several petitions and notes concerning the recognition of noble and princely rights and termination of this protract-

${ }^{51}$ Letters from governor general of Novorossiya Michael Semyonovich Vorontsov to Andrey Mikhailovich Fadeyev on matters official, peasants of the Saratov estates of M.S. Vorontsov' and permission to R. A. Fadeyev to live in Tiflis // RSHA. Fund 1100. Record 1. Document 13. Sheets 5-7.

52 Letter exchange between V.P. Butkov and chief administrator of the viceroy's chancellery S. V.Safonov on administering the Caucasian viceroyalty // RSHA. Fund 1250. Record 2. Document 10. Sheet 137.

53 ACA. Tiflis, 1885. C. XXXII.

54 See more: Urushadze A. T. Another Caucasian war: the Caucasian viceroy vs tsar's ministers (18441853) // Ural'skiy istoricheskiy vestnik. 2019. No. 3. P.31-39.

${ }_{55}$ Letter exchange between V.P. Butkov and chief administrator of the viceroy's chancellery S. V. Safonov on administering the Caucasian viceroyalty // RSHA. Fund 1250. Record 2. Document 10. Sheet 74. 
ed case" 56 . However, despite all efforts on the part of the viceroy's administration and the head of the Caucasian committee V.P. Butkov, proper acknowledgment of the Georgian nobility was legally supported only five years later, on 6 December $1850^{57}$.

M.S. Vorontsov was considered a protector of interests of the Georgian aristocrats, and the most conspicuous fact confirming this statement is his unconditional protectorship of the Orbeliani family. In his letters to V. P. Butkov, the Caucasian viceroy repeatedly reminds him about his petitions for awarding members of the Orbeliani family with decorations, and requests the head of the Ministers committee to assist the princely Georgian family. So what was the reason behind such attitude on behalf of the viceroy?

As remembered by A. M. Fadeyev, M. S. Vorontsov felt affection towards the Orbeliani princes during his service in the Caucasus under P.D. Tsitsianov back in 1803-1805. The then count Micael Semeyonovich, accompanied by the Georgian princes, passed through the Lori steppe (Alexandropol uyezd of the Erivan governorate), which the Orbeliani considered their domain. In reality, the Georgian princes held no lawful rights to claim the territory as theirs, but this fact did not prevent them from assuring M.S. Vorontsov that their claim was legitimate. Forty years later, having returned to the Caucasus as a viceroy, M.S. Vorontsov was quick to settle the matter of the Lori steppe finally in favour of the Orbeliani princes. Formally, he succeeded in that; but given some obvious discrepancies in the set of documents on ownership of the disputed territory, Orbeliani could not assume possession of it ${ }^{58}$. The new viceroy, N. N. Murav'yev, having thoroughly studied the complicated case, made a query to the Caucasian committee to re-examine the case in $1856^{59}$. The detailed enquiry by N.N. Murav'yev was left unanswered for a period of a year. It does not deem possible to give an unambivalent answer as to why the Committee was so slow to provide a reply, but we would imagine that a certain role was played by M.S. Vorontsov's letter to V.P.Butkov of 14 September 1854, where the former viceroy wrote about the Orbeliani's family problems with administering their land property ${ }^{60}$. Michael Semeoynovich noted that should the case be solved to the benefit of Orbeliani family, "the number one family of Georgia will be prosperous and will not be coerced, as they are now, to take

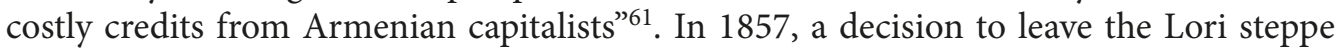
with the Orbeliani was made in the Caucasian committee. A. I. Baryatinskiy, the Caucasian viceroy at the time who had promised to M.S. Vorontsov to solve the case in favor of the Georgian princes in the summer of 1856 during coronation of Alexander II, agreed with the decision of the Caucasian committee.

V.P.Butkov never left letters from the aged ex-viceroy unattended. Some letters to the chief administrator of the Caucasian committee M.S. Vorontsov began with a telling phrase: "My good man Vladimir Petrovich, you spoiled me so much with your constant

56 On the recognition of princely and noble families in Georgia, Imereti and Guria, and on the establishment of special commissions for consideration of their documents in Tiflis and Kutais and on the composition of the latter // RSHA. Fund 1268. Record 1. Document 858. Sheet 4.

57 Complete body of laws of the Russian Empire. Collection II. Vol. XXV, part 2. St. Petersburg, 1851. P. 273.

58 See more: Fadeyev A. M. Memoirs 1790-1867. P. 309-314.

59 On a submission from the Caucasian viceroy general aide-de-camp Murav'yev: on lands in Alexandropol'skiy uyezd of the Erivan governorate in dispute between the princely family of Orbeliani and the state // RSHA. Fund 1268. Record 8. Document 80. Sheet 37.

${ }^{60}$ Letter exchange between V.P. Butkov and M.S. Vorontsov on administering the Caucasian viceroyalty // Russian State Historical Archive (RSHA). Fund 1250. Record 2. Document 12. Sheets 25-31.

61 Ibid. Sheet 27. 
benevolence and your efficient actions in the Caucasian matters that I write to you with no remorse..." ${ }^{\prime 2}$. That is exactly how Michael Semyonovich's letter of 7 February 1856, where he asked V.P.Butkov for assistance in yet another case of the Orbeliani princes, began. Under the court decision, the Georgian princes were to pay 80 thousand roubles in silver, which could completely devastate their finances. M.S. Vorontsov bought off their debt for 22 thousand roubles, but asked for V.P. Butkov's help in order for the case to be decisively solved in favour of the Orbeliani. "Although I surely would be happy to have my 22 thousand roubles returned to me, I wish this case a just solution for the good of the Orbeliani themselves; I love many of them and I only mean them well", wrote M. S. Vorontsov ${ }^{63}$.

Makariy Fomich Orbeliani was the closest member among all the Orbeliani family to M.S. Vorontsov ${ }^{64}$, whom the latter addressed simply 'Mamuka' in his diary and letters. A.M. Fadeyev spoke of him as a favourite of the viceroy, having also characterized him as a "brave, clever, very amiable Georgian man" 65 . In August 1853, a mail coach was robbed of a large sum of government money in Elizavetapolskiy uyezd. Head of the uyezd, F. M. Orbeliani, sent the expensive cargo without being appropriately convoyed. Robbers successfully took advantage of that fact. The incident could have brought about no consequences for F. M. Orbeliani given his informal relationships with the viceroy. However, a detailed report of the incident was received by the Caucasian committee. The members of the Committee found the grounds for accusations trustworthy, and the viceroy's favourite was to recover the full sum in the form of sequestration of land property of the family.

In his letter to S. V. Safonov of 3 August 1854, M. S. Vorontsov pointed out that this case had "touched" him "to the bottom of his heart"66. The viceroy emphasized that the injustice towards "kind Mamuka and his amiable family" made "all Georgian nobility feel sad and heartsore". Michael Semeoynovich asked for A. I. Chernyshev's help, and S. V. Safonov received the following instructions from M.S. Vorontsov: “...have a talk with our honourable Vladimir Petrovich (Butkov. - A. U., Z.S.) as soon as you can, you know everything that pertains to Mamuka, his family affairs and the Georgian nobility on the whole" ${ }^{67}$. M.S. Vorontsov noted that he asked S. V.Safonov to make every possible effort and, if successful, he would deserve gratitude not only from his acquaintances, but also from the whole of Georgia.

M.F. Orbeliani blissfully avoided the potentially devastating payment; Vorontsov's protection redeemed the Georgian family from serious trouble. The Orbeliani succeeded in retaining their influence under other viceroys as well. In 1859, prince G.D. Orbeliani took charge of the Counsel of the Caucasian viceroy A. I. Baratyanskiy; he was responsible for the development of the land reform project for the Northern Caucasus, which was consequently carried out in the region starting from $1863^{68}$.

Finance of Tiflis and of the whole of Transcaucasia were in the hands of Armenian merchants. General M. Y. Ol'shevskiy remembered: “The richest men of Tiflis and its main

${ }^{62}$ Letter exchange between V. P. Butkov and M. S. Vorontsov... // RSHA. Fund 1250. Record 2. Document 12. Sheet 30 .

63 Ibid. Sheet 36.

${ }^{64}$ Gogitidze M. Georgian generalship (1699-1921). Handbook of biographies. Kyiv, 2001. P. 129.

65 Fadeyev A. M. Memoirs 1790-1867. P. 356.

${ }^{66}$ Letter exchange between V.P. Butkov and M.S. Vorontsov... // RSHA. Fund 1250. Record 2. Document 12. Sheet 22.

67 Ibid.

${ }^{68}$ North Caucasus as part of the Russian Empire. Moscow, 2007. P. 217. 
owners are Armenians; all trade is in their hands"69. "Guide and companion for a travel across the Caucasus" gave the following data: "It is almost unbelievable, but is nevertheless true, that in 1803, there were up to 2700 households in Tiflis, out of which only four 4 households belonged to Georgians proper and 15 to Georgian princes, while the rest were Armenian; therefore, the Georgian capital belonged back then, on the whole, to Armenians"70. According to the statistics of the "Caucasian calendar", there were 1926 artisans in Tiflis in the year of 1847, of which 1448 were Armenians ${ }^{71}$. M.S. Vorontsov began building rapport with the Armenian elite upon his arrival in Tiflis. This was facilitated by his old liaisons with Armenian patriarch Nerses V, the relationship with whom had been was founded in 1803 when the young count M.S. Vorontsov was serving under P.D. Tsitsianov, and archimandrite Nerses was a negotiator of the khan of Erivan. In 1828-1843, Nerses occupied the position of the head of the eparchy of the region of Bessarabia and had regular meetings with the governor general of Novorossiya, M. S. Vorontsov, in Odes$\mathrm{sa}^{72}$. The informal relationship with patriarch Nerses $\mathrm{V}$ made mutual understanding between the viceroy and influential Armenian merchants significantly easier.

Ivan Mirzoev, who was engaged in fishing and sericulture, commanded the most sizable respect among the Armenian merchants. The Caucasian viceroy asked V.P. Butkov in a letter to the latter of 6 October 1852, for his assistance in successful review of Ivan Mirzoev's award recommendation for order of St. Anne, $2^{\text {nd }}$ degree: "I ask your excellency earnestly not to reject the request to decorate him with the order that I am asking for him" ${ }^{\text {"73 }}$. We would like to note that by the time the viceroy recommended Ivan Mirzoyev, Mirzoyev had already been a cavalier of St. Stanislav, $4^{\text {th }}$ degree, for several years. Along with the letter to V.P. Butkov, M.S. Vorontsov sent a note to A.I. Chernyshev, with recommendation to award the Armenian merchant, in which the viceroy stated, "Over the seven years of my administering the Caucasus, I have always found in Mirzoyev a man not only ready to assist the government each time I asked for assistance, but also a man who has proved to be useful in terms of advice, self-denying and always eager to help me in the country's interest... Whoever that is who is in my place, be it me or someone other, let Mirzoyev always be turned to for advice and his weight in the eye of the public opinion"74.

Before leaving for a health vacation in spring 1854, M.S. Vorontsov left detailed instructions to general N.A. Read, who stepped up to temporarily occupy the position of the viceroy. Having emphasized the importance of the Armenian merchants for successful development of the Caucasian region, M.S. Vorontsov especially recommended Ivan Mirzoyev: "He rendered us very great services by taking over many affairs for which there were no eager performers, or by finding such..."75

Vorontsov's recommendations were not left without due attention. Mirzoev not only received new awards, but also remained close to the imperial administration under A.I. Baryatinsky. M.S. Vorontsov also recommended other Armenian merchants for

${ }^{69}$ Ol'shevskiy M. Y. The Caucasus 1841 through $1866 \ldots$

70 Vladykin M. Guide and companion for a travel across Caucasus. Moscow, 1885. P. 223.

${ }^{71}$ Caucasian calendar for 1847. Tiflis, 1846. P. 163.

72 Zakharova O. Y. Filedmarshal general, his serene highness prince M. S. Vorontsov. Cavalier of the Russian Empire. Moscow, 2001. P. 352.

${ }^{73}$ Letter exchange between V.P.Butkov and M.S. Vorontsov... // RSHA. Fund 1250. Record 2. Document 12. Sheet 12 .

${ }^{74}$ Ibid. Sheets $15-16$.

75 ACA. Tiflis. P. 97. 
awards, including such influential ones as Arshakuni and Mirimanov. However, it is obvious that the greatest trust of the viceroy was enjoyed by Ivan Mirzoyev.

"Semper immota fides" ("Eternal unshrinking loyalty") is the motto on the Vorontsov family coat of arms. M.S. Vorontsov was undoubtedly loyal to the Romanov dynasty and served the Russian empire for his whole life. However, there was also another kind of loyalty - loyalty to his party. The Caucasian viceroy consistently advocated the interests of his employees, supported their careers, provided protection during periods of official headwinds. He succeeded in developing a well-knit patronage network in the Caucasus, which excluded opposition and was at the basis of the regional autocracy of the viceroy. Forming a loyal fraction was also necessary in the context of opposing bureaucracy of ministries, connections of which with the local institutions were cut short or made utterly formal. Promotions, awards and supporting clients' material wealth ensured their loyalty. The system laid out by M.S. Vorontsov proved to be long-lasting. His successors also relied upon the Caucasian committee and its head in the capital, and within the viceroyalty territory - on same corporations and particular individuals that were patronized by the first Caucasian viceroy.

\section{References}

Bartlett R. Prince Michael Vorontsov: Viceroy to the Tsar by Anthony L. H. Rhinelander. The Journal of Modern History, 1994, vol.66, no. 3, pp.660-661.

Gogitidze M. Georgian generals (1699-1921). Biographical reference. Kiev, 2001, 232 p. (In Russian)

Il'in P. V. M.S. Vorontsov and his entourage. Iz glubiny vremen, 1995, no. 4, pp. 53-60. (In Russian)

Lapin V.V. Russian army in the Caucasian war. St. Petersburg, Evropeiskii dom Publ., 2008, 400 p. (In Russian)

Lang D. The Last Years of the Georgian Monarchy, 1658-1832. New York, Columbia University Press, 1957, $333 \mathrm{p}$.

Lazarian S.S. Military-political and administrative-legal activity of Prince M. S. Vorontsov in the Caucasus region, 1845-1854. Piatigorsk, PGLU Publ., 2012, 322 p. (In Russian)

Rhinelander A. Prince Michael Vorontsov. Viceroy to the Tsar. Montreal, McGill-Queen's University Press, 1990, $279 \mathrm{p}$.

Rhinelander A. The Creation of The Caucasian Vicegerency. The Slavonic and East European Review, 1981, vol. 59, no. 1, pp. 15-40.

Suny R. The Making of the Georgian Nation. Bloomington, Indianapolis, Indiana University Press, 1994, $419 \mathrm{p}$.

Tygel'skii V. The fraction that couldn't lose. Patron-klientskie otnosheniia v istorii i sovremennosti. Moscow, Politicheskaia entsiklopediia Publ., 2016, pp. 116-148. (In Russian)

Urushadze A. T. The other Caucasian war: Caucasian Viceroy vs the tsar's ministers (1844-1853). Ural'skii istoricheskii vestnik, 2019, no. 3, pp.31-39. (In Russian)

Zakharova O. Iu. Prince M.S. Vorontsov. Knight of the Russian Empire. Moscow, Centrpoligraf Publ., 2001, 381 p. (In Russian)

Статья поступила в редакцию 26 ноября 2019 г.

Рекомендована в печать 12 марта 2020 г.

Received: November 26, 2019

Accepted: March 12, 2020 